\title{
Determinants of Fishery Sub Sectors Performance in Riau Island Province
}

\author{
Widiyarini $^{1}$, Achmad Rodoni ${ }^{2}$, Darwati Susilastuti ${ }^{3}$, Dona Fitria ${ }^{4}$ \\ \{widiya2513@gmail.com¹, rodoni@borobudur.ac.id², \\ darwatisusi@borobudur.ac.id/darwati_susilastuti@borobudur.ac.id ${ }^{3}$ \} \\ Universitas Indra Prasta Jakarta ${ }^{1}$, Universitas Islam Negeri Syarif Hidayatullah Jakarta ${ }^{2}$, \\ Universitas Indra Prasta Jakarta ${ }^{3,4}$
}

\begin{abstract}
Riau Islands Province has a large potential of fishery resources but has not been utilized optimally to increase regional economic growth, in addition to the problem of territorial boundaries in the South Natuna Sea between Indonesia and Vietnam and China, as well as a decrease in the number of Indonesian fishing fleets operating in the province. The Riau Archipelago is faced with the proliferation of foreign fishing vessels looking for fish in the region. The purpose of this study is to find and analyze the effect of domestic investment, fishery business credit, fishery exports and the number of fishing fleets on the performance of the fisheries sub-sector in the Riau Islands Province. In this research, the natural logarithm equation $(\mathrm{Ln})$ model is used, with explanatory research analysis research methods or hypothesis research through explanations of causal relationships between variables, while the research design uses panel data analysis cross section 7 cities/districts and time series for 6 years from 2015 to 2020 in the Riau Islands Province using quantitative inferential statistics. The result show that the variables of domestic investment, fishery business credit, fishery exports and the number of fishing fleets simultaneously have a significant effect, also partially have a significant and positive effect on the performance of the fisheries sub-sector in the Riau Islands Province. Likewise, the fishery subsector performance variable has a significant and positive
\end{abstract}

Keywords: Fishery Sub Sectors Performance; Domestic Investment; Fishery Business Credit; Fishery Export; Fishing Armada Numbers

\section{Introduction}

The successful achievement of regional development through economic development must be adjusted to the conditions and potentials of each region and a coordinated development plan between categories is required. Development planning aims to thoroughly analyze the potentials possessed by a region. The discussion of the leading sectors and the potential of the regional economy is a strategy for determining regional economic growth in the era of autonomy each region is competing to increase regional economic growth. This is very important for local governments in determining the efforts that can be made to encourage economic growth in their regions. Therefore, the utilization and development of all economic potential is a top priority 
that must be explored and developed in carrying out sustainable regional economic development $[1]$.

One of the sectors that can support economic development is the fisheries sub-sector. The marine and fishery sector is one of the economic sectors that has a role in regional economic development, especially in the provision of protein foods and providing employment. However, ironically, the fishery sector has not received special attention from the government and business circles, even though if this sector is managed seriously it will make a greater contribution to regional economic development and can reduce the poverty level of local communities, especially fishing communities and capture fisheries entrepreneurs.

The development of the fishery sector is part of the economic development that has been carried out so far and has experienced ups and downs, at one time the fishery sector was used as a superior in increasing people's and government's income, but at other times less attention was paid to it. One of the responses shown by the central government is the change in policy of wider autonomy to the regions, namely the granting of authority to local governments to determine the direction of regional development policies which are expected to influence national development targets. The development of the fisheries sector needs to be directed at increasing its role in creating linkages with other sectors through increasing added value, employment, and increasing income, as well as strong linkages with other sectors, both forward and backward linkages, which in turn will grow activities. economy.

Riau Islands Province (Kepri Province) is the 32nd Province in Indonesia which was established by Law Number 25 of 2002. Administratively, Riau Islands Province has two cities, namely Tanjungpinang City as the Provincial Capital and Batam City, and has five districts, namely: Karimun, Bintan Regency, Natuna Regency, Lingga Regency, and Anambas Islands Regency. According to BARENLITBANG data for the Riau Islands Province (2017), the Riau Islands Province has an area of 251,810.71 km2, consisting of $241,215.3 \mathrm{~km} 2(96.79 \%)$ sea and $10,595.41 \mathrm{~km} 2(4.21 \%)$ land and 2,367 coastlines. , $6 \mathrm{~km}$, with such conditions, of course the Riau Islands Province has a very large marine and fishery potential, which consists of various marine fishery products.

As an archipelagic region, the fisheries sub-sector is one of the economic bases for regional development in the Riau Islands Province in accordance with the regional development mission in the Regional Medium-Term Development Plan (RPJMD). Given the potential for fish resources owned by the Riau Islands waters which are included in the Fishery Management Area (WPP) 711, it is quite large reaching 1,059,050 tons/year and is estimated to have fish resource potential of $860,650.11$ tons/year including large pelagic fish of 53,802.34 tons/year, small pelagic fish 506,025.30 tons/year, demersal fish 272,594.16 tons/year, reef fish 17,562.29 tons/year, others (squid, shrimp, lobster) 10,666.02 tons/year as stated in the Regulation of the Minister of Marine Affairs and Fisheries Number: 45/MEN/2011 concerning Estimation of Potential Fish Resources in the Fisheries Management Area of the Republic of Indonesia. The largest capture fisheries potential in the Riau Islands Province is in Natuna waters with a new utilization rate of $4-6 \%$ of the total potential of Natuna Regency of 504,212.85 tons/year (58.59\% of the total potential of Riau Islands Province), followed by Bintan Regency, Archipelago Regency Anambas, and Lingga Regency.

The GRDP of the Fishery Sub-Sector at Constant Prices (ADHK 2010) in the Riau Islands Province is one of the proxy indicators to see the performance of the fisheries sub-sector in the Riau Islands Province. GRDP of the Fisheries Sub-sector is the amount of added value for goods and services produced by the fisheries sub-sector. The economic growth of the fishery subsector is a change in the GRDP of the fishery sub-sector from one period to the next. The GRDP 
of the fisheries sub-sector is only based on the primary sector which includes capture fisheries and aquaculture (BPS Province of Riau Islands).

Fisheries are one of the agricultural sectors that have a major contribution to the economy of the Riau Islands Province, if these resources are used optimally. In general, there are two types of fisheries, namely land and sea. For the Riau Islands Province, the potential for marine fisheries is very dominant, supported by most of the coastal areas. Utilization of marine resources can become a circular flow of the economy so that it can improve the welfare of the community in a sustainable manner. In addition, the output generated from the fisheries subsector is large enough to meet the nutritional and protein needs of the community.

The performance of the fisheries sub-sector of Riau Islands Province during the period 2015 to 2019 continued to increase, from Rp. 3,792.64 billion in 2015 to Rp. 4,453.95 billion in 2019 or an average growth of 4.10 percent/ year. While the highest year to year (y-to-y) growth rate occurred in 2016 at 5.33 percent and the lowest in 2018 at 2.75 percent, the increase in the performance of the fisheries sub-sector is an indication of an increase in economic growth. However, the growth in the value of the performance of the fisheries sub-sector from 2015 to 2019 is still not able to utilize optimal resource potential, the utilization of capture fisheries resource potential is not optimal compared to the existing potential (potential 1,057,050/year compared to the utilization rate of Riau Islands fishermen which is only 407,235.91 or 38.5 percent) and aquaculture production compared to existing potential (potential for marine cultivation of 455,780 ha, utilization of 2,281 ha or 0.5 percent), as well as limited aquaculture facilities (fish seeds and fish feed) (DKKP Riau Islands Province, 2019)

In 2020 the value of GRDP in the Fisheries Sub-sector of Rp. 4,357.11 experienced negative pressure, growing by -2.17 percent. The weakening economic growth of the fishery sub-sector in 2020 is closely related to the Covid 19 pandemic. The pandemic that hit at the end of March 2020 has resulted in reduced economic activity which has reduced demand for fishery commodities. On the other hand, the pandemic coincided with the fishing season, where there was an abundance of catch. The abundance of availability coupled with low demand has resulted in the weakening of fishery commodity prices so that the fishery sub-sector experienced negative growth.

Research related to the fisheries sub-sector GRDP conducted by several researchers: Gaurahman \& Arka (2020), explained that the fisheries sub-sector has a significant influence on the economic growth (GRDP) of Mimika Regency. If there is an increase in the production of the fisheries sub-sector, it will be accompanied by an increase in economic growth (GRDP) of Mimika Regency. Increased economic growth through the GRDP indicator which means it will also improve the welfare of the community. Further research by Agustiani \& Syechalad (2016) observed the contribution of the fisheries sub-sector to GRDP in 23 districts/cities in Aceh Province. The results showed that aquaculture production was positive and greatly affected GRDP. This result is also in line with Teniwut's (2016) research that the production of the fishery sub-sector has a positive effect on Maluku's GRDP.[26] However, the fisheries subsector will face several challenges in the long term, such as expectations of high fish prices in the future, exploitation of fish resources and illegal fishing which will hamper production

\section{Literature Review}

\subsection{Fishery}


Fisheries are all activities related to fish, including producing fish, either through catching (capture fisheries) or cultivation and or processing them to meet human needs for food as a source of protein and non-food (tourism, ornamental fish and others). The scope of fishery business activities does not only produce fish (on farm), but also includes off farm activities, such as procurement of production facilities and infrastructure, processing, marketing, capital, research and development, legislation, and other supporting business factors. Types of fishery business are divided into three, among others: Business through catching, business through cultivation and fish processing business. According to Hempel and Pauly (2002), fisheries are activities of exploiting biological resources from the sea [2]. The definition of fishery he expressed is limited to marine fisheries, because fisheries are indeed all derived from hunting activities which must be distinguished from farming activities such as cultivation.

Meanwhile, according to Lackey (2005) fisheries is a system consisting of three components, namely aquatic biota, biota habitat and humans as users of these resources. Of these components will affect the performance of the fishery [3]. According to Mubiyarto (1994), fisheries are all business catching fish cultivation and management activities to marketing [4]. While fishery resources are all animals and plants that live in waters (both on land and sea), therefore fisheries can be distinguished into land fisheries and marine fisheries. Inland fisheries are all fishing businesses that are not carried out in the wide sea such as freshwater fisheries, ponds, ponds and so on. Especially for fisheries in the sea, marine biologists distinguish marine fisheries into two groups, namely pelagic fish (fish that live on the surface) and demersal fish (fish that live on the seabed). The pelagic fish groups include skipjack, tuna, kite, mackerel, seagrass and others. While the types of demersal fish such as shrimp, crab, red snapper and others.

\subsection{Investment}

Investment by some economists is defined as spending to buy capital goods or production equipment with the aim of replacing and especially adding goods and services in the future. Investment is often known as investment or capital formation. According to Mankiw (2014) investment is the purchase of goods that will be used in the future to produce more goods and services. Investment can be divided into two types, namely real investment and financial investment. What is meant by real investment is investment in durable goods that will be used in the production process. While financial investment is an investment in securities, for example the purchase of shares, bonds, and other proof of debt. According to Sukirno (2016), investment is defined as the expenditure or expenditure of investments or companies to buy capital goods and production equipment to increase the ability to produce goods and services available in the economy. In other words, in economic theory, investment means spending activities to increase production capacity in the economy. Investment activities carried out by the community will

continuously increase economic activities and job opportunities, increase national income and increase the level of community prosperity.

\subsection{Banking Credit}

Credit is a financial facility that allows a person or business entity to borrow money to buy a product and repay it within a specified period of time. Giving credit is the main activity of banks and finance companies (multi). According to Rivai et al (2013) credit is the delivery of 
goods, services or money from one party (creditor) on the basis of trust to another party (customer or debtor) with a promise to pay from the credit recipient to the creditor on a date agreed by both parties. The definition of credit according to the Banking Law number 10 of 1998 is the provision of money or bills that can be equated with it, based on an agreement or loan agreement between a bank and another party that requires the borrower to repay his debt after a certain period of time with interest (Kasmir, 2013). Credit is all types of loans that must be repaid with interest by the borrower in accordance with the agreed agreement (Hasibuan, 2011). Meanwhile, according to (Suyanto 2011) credit is the right to receive payment or the obligation to make payments when requested or at a future time because of the delivery of goods now. Based on the above understanding, it can be concluded that credit is the provision of loans in the form of money or bills based on an agreement or agreement between the bank and the borrower which requires the borrower to pay off his debt within a certain period of time with interest.

\subsection{Export}

Export is an activity of removing goods from the Indonesian customs area to the customs area of another country. Usually the export process begins with an offer from one party accompanied by approval from another party through a sales contract process, in this case the Exporter and Importer. The payment process for this shipment can be through the Letter of Credit $(\mathrm{L} / \mathrm{C})$ or non-L/C method, each method has its own risks and benefits. (DJPEN Ministry of Trade, 2021). Export is trade by removing goods from inside to outside the Indonesian customs territory by complying with the applicable provisions. (Andri Feriyanto, 2015, p.75). Meanwhile, export activity is a trading system by releasing goods from within the country to abroad by fulfilling the applicable provisions. Exports are the total goods and services sold by a country to other countries, including goods, insurance, and services in a given year (Adrian Sutedi, 2014, p.7). Exports can be seen from the supply and demand side.

The purpose of the theory of demand (demand) and supply (supply) is to describe how prices can be formed in the market mechanism. The meeting between these two laws in one condition is an ideal condition expected by business people. Such an ideal condition in economics is known as the equilibrium point. The simplest theory of demand in the law of demand states that: if the price of an item increases, the quantity demanded of a good will decrease, otherwise if the price of an item falls then the quantity of the good demanded will decrease. requested will increase. The law of demand will apply with the assumption that other factors other than price must be held constant (Ceteris Paribus). This is the original concept of its inventor, namely Alfred Marshall in Ahman (2009, p.93). Indonesian fishery product export commodities include shrimp, tuna, grouper, snapper, mackerel, tilapia, cephalopods (squid, octopus, cuttlefish), crab meat, crab, seaweed, sea cucumber, lobster. These fishery commodities are processed into fishery products in the form of final products. The process of handling and processing fish products is divided as follows: (Export Warta, DJPEN Ministry of Trade, 2014, p.5) 1) Product live. 2) Fresh product through the cooling process. 3) Frozen product, either raw or cooked through the freezing process. 4) Canned products go through a high temperature heating process (sterilization) and pasteurization. 5) Dried product through natural or mechanical drying process. 6) Dry salted product through natural or mechanical salting and drying process. 7) Smoked products go through a smoking process. 8) Fermented products through the fermentation process. 9) Cooked products go through a cooking/steaming process. 10) Surimi based product, through a leaching or pressing (minched) process. 


\subsection{Fishing Fleet}

A ship is a form of construction that can float in water and has the property of loading in the form of passengers or goods, the nature of which can be moved by oars, wind or engines (Fachrussyah and Junus, 2016, p. 2). Furthermore, it is said that fishing boats is one type of ship, because the requirements required by a ship are also required by fishing vessels, but unlike other types of ships, fishing vessels have more complicated and heavy operational functions. Fishing vessel is a vessel used to catch fish, including accommodating, storing, refrigerating and/or preserving fish. Meanwhile, fish transporting ship is a ship that has a hold and/or is specifically used to transport, load, accommodate, collect, store, refrigerate, and/or preserve fish. According to Nomura and Yamazaki (1977) in Fachrussyah (2016, p. 3) stated that fishing vessels are different from other types of vessels so that fishing vessels have several features that distinguish them from other types of vessels.

Indonesian-flagged fishing vessels that carry out fishing activities in the fishery management area of the Republic of Indonesia are required to use Indonesian captains and crew members. Meanwhile, foreign-flagged fishing vessels that carry out fishing activities in the ZEEI are required to use Indonesian crew members at least $70 \%$ (seventy percent) of the total crew members. Indonesian fishing vessels operated in the Indonesian fishery management area must first be registered as Indonesian fishing vessels. The registration of fishing vessels is accompanied by documents in the form of proof of ownership, owner's identity, and a letter of measurement. Registration of fishing vessels purchased or obtained from abroad and already registered in the country of origin to be registered as Indonesian fishing vessels, in addition to the above documents, must also be accompanied by a certificate of deletion from the list of vessels issued by the country of origin.

\subsection{Research Hypothesis}

a. Domestic investment, fishery business credit, fishery exports, and fishing fleets have a positive effect on the performance of the fisheries sub-sector in the district/city of the Riau Archipelago Province.

b. Domestic investment has a positive effect on the performance of the fisheries sub-sector in the districts/cities of the Riau Archipelago Province.

c. Fishery business credit has a positive effect on the performance of the fisheries subsector in the district/city of the Riau Archipelago Province.

d. Fishery exports have a positive effect on the performance of the fisheries sub-sector in the district/city of the Riau Archipelago Province.

e. The fishing fleet has a positive effect on the performance of the fisheries sub-sector in the district/city of the Riau Archipelago Province.

\section{Methodology}

\subsection{The Scope of Research}

The place or object of research data is carried out in the Riau Islands Province by making direct observations in several districts and cities such as Bintan district, Karimun district, Anambas archipelago district, Lingga district, Natuna district, Batam city and Tanjung Pinang 
city which are locations where the capture fisheries sector is located. and aquaculture is growing rapidly.

\subsection{Population and Sample Research}

In this study, what is meant by population is all data on research variables from 2002 since the formation of the Riau Islands Province until 2020 which relates to all variables to be studied. While the sample used in this study is research variable data from 2015 to 2020 using panel data related to domestic investment, fishery business credit, fishery exports, the number of fishing fleets. The sample used in this study is cross section data of 7 (seven) cities and regencies and time series data for 6 (six) years of research from 2015 to 2020, so that the sample of this study amounted to 42 (forty-two) samples.

\subsection{Research Design}

The research design used is explanatory research analysis or hypothesis research through explanation. Explanatory research is an analytical tool to explain the causal relationship between variables by testing the hypothesis. The explanatory format is to describe a generalization or explain the relationship of one variable to another, therefore explanatory research uses hypothesis testing using inferential statistics (for hypothesis testing), according to Bungin's opinion (2013, p. 51).

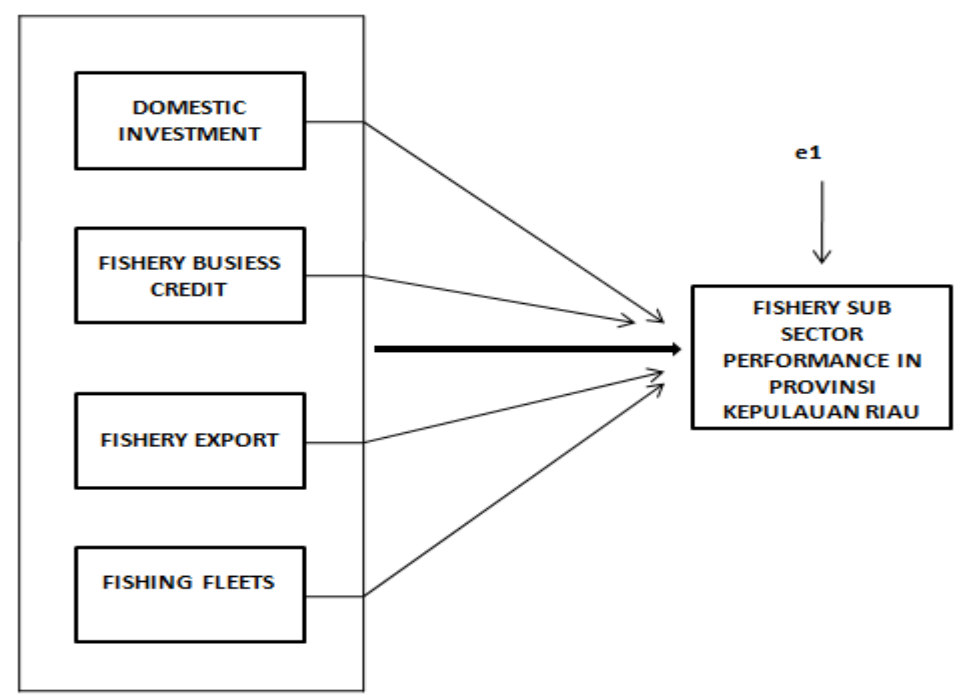

Fig. 1. Research Scheme

The analysis includes a causal relationship based on theories, literatures, journals and previous studies either through direct observation or internet data.

\section{Results and Discussion}




\subsection{Results}

\subsubsection{Hypothesis Test Results}

To determine the most appropriate Fixed Effect or Common Effect model used in estimating panel data, the Redundant Fixed Effect Test is carried out. The condition is that if the probability is 0.05 , then Ho is accepted, meaning that the common effect model (pool least square) will be used. But if the probability value is $<0.05$, then $\mathrm{H} 1$ is accepted, meaning that it uses a fixed effect approach. The results of the Redundant Fixed Effect Test in this study are:

Table 1. Redundant Fixed Effect Test

\begin{tabular}{lccc}
\hline $\begin{array}{l}\text { Redundant Fixed Effects Tests } \\
\text { Pool: DATAPANEL } \\
\text { Test cross-section fixed effects }\end{array}$ & & \\
\hline \multicolumn{1}{c}{ Effects Test } & Statistic & d.f. & Prob. \\
\hline Cross-section F & 5335.977372 & $(6,31)$ & 0.0000 \\
Cross-section Chi-square & 291.520631 & 6 & 0.0000 \\
\hline
\end{tabular}

Source: Data processed Eviews 10

The results of the Redundant Fixed Effect test in Table 1 show the cross-section probability value $\mathrm{F}=0.0000<0.05$ and the Chi Square Cross Section Value $0.0000<0.05$ so that Ho is rejected and $\mathrm{H} 1$ is accepted, meaning that the correct fixed effect model is used compared with common effects to estimate panel data. After the Chow test was carried out and obtained the results that the fixed effects model was used, the panel data model had to be compared again between fixed effects and random effects using the Hausman test. The Hausman test is used to determine whether the fixed effect model or the random effect model is the most appropriate. The conditions are, if the probability of Chi-Square (0.05), then Ho means that the random effect is accepted, if the probability value of Chi-Square $<(0.05)$, then the fixed effect is accepted. The results of the Hausman test in this study are:

Table 2. Hausman Test

\begin{tabular}{|c|c|c|c|}
\hline \multicolumn{4}{|c|}{$\begin{array}{l}\text { Correlated Random Effects - Hausman Test } \\
\text { Pool: DATAPANEL } \\
\text { Test cross-section random effects }\end{array}$} \\
\hline Test Summary & Chi-Sq. Statistic & Chi-Sq. d.f. & Prob. \\
\hline Cross-section random & 23.521869 & 4 & 0.0001 \\
\hline
\end{tabular}

Source: Data processed Eviews 10

The Hausman test results in Table 2 show the random cross section probability value of $0.0001<0.05$ so that Ho is rejected and H1 is accepted, meaning that the correct fixed effects model is used compared to random effects to estimate panel data. The following are the results of the regression using the Fixed Effect model:

Table 3. Fixed Effect Test

Dependent Variable: Ln PERIKANAN?

Method: Pooled Least Squares

Date: 06/20/21 Time: 19:27

Sample: 20152020

Included observations: 6

Cross-sections included: 7 


\begin{tabular}{|c|c|c|c|c|}
\hline \multicolumn{5}{|c|}{ Total pool (balanced) observations: 42} \\
\hline Variable & Coefficient & Std. Error & t-Statistic & Prob. \\
\hline $\mathrm{C}$ & 6.171254 & 1.063860 & 5.800815 & 0.0000 \\
\hline Ln_INVESTASI? & 0.022345 & 0.010893 & 2.051290 & 0.0488 \\
\hline Ln KREDIT? & 0.334903 & 0.101243 & 3.307926 & 0.0024 \\
\hline Ln_EKSPOR? & 0.571480 & 0.124202 & 4.601201 & 0.0001 \\
\hline Ln_ARMADA? & 0.059547 & 0.028741 & 2.071816 & 0.0467 \\
\hline \multicolumn{5}{|l|}{ Fixed Effects (Cross) } \\
\hline KARIMUN--C & -0.987174 & & & \\
\hline BINTAN--C & 0.386532 & & & \\
\hline NATUNA--C & 1.352570 & & & \\
\hline LINGGA--C & 0.882766 & & & \\
\hline ANAMBAS--C & 0.799825 & & & \\
\hline BATAM--C & -1.093942 & & & \\
\hline TJ_PINANG--C & -1.340577 & & & \\
\hline \multicolumn{5}{|c|}{ Effects Specification } \\
\hline \multicolumn{5}{|c|}{ Cross-section fixed (dummy variables) } \\
\hline R-squared & 0.899761 & \multirow{2}{*}{\multicolumn{2}{|c|}{$\begin{array}{l}\text { Mean dependent var } \\
\text { S.D. dependent var }\end{array}$}} & 6.107844 \\
\hline Adjusted R-squared & 0.899684 & & & 0.892030 \\
\hline S.E. of regression & 0.015862 & \multicolumn{2}{|c|}{ Akaike info criterion } & -5.229637 \\
\hline Sum squared resid & 0.007800 & \multicolumn{2}{|c|}{ Schwarz criterion } & -4.774533 \\
\hline Log likelihood & 120.8224 & \multirow{2}{*}{\multicolumn{2}{|c|}{$\begin{array}{l}\text { Hannan-Quinn criter. } \\
\text { Durbin-Watson stat }\end{array}$}} & -5.062824 \\
\hline F-statistic & 12963.31 & & & 1.725533 \\
\hline Prob(F-statistic) & 0.000000 & & & \\
\hline
\end{tabular}

The calculation results in Table 3 can be presented with the results of multiple linear regression of panel data as follows:

$Y_{1}=6.171254+0,022345 X_{1}+0,334903 X_{2}+0,571480 X_{3}+0,059547 X_{4}$

The interpretation of the regression equation is as follows:

a. Constant value $o=6.171254$ means that statistically if all the independent variables ceteris paribus have a constant value, then the Fishery Sub-Sector Performance value is 6.171254 percent

b. The value of the Regression Coefficient $1=0.022345$, meaning that the elasticity value of domestic investment on the performance of the fisheries sub-sector is $\mathrm{E}=0.022345$. The value of $\mathrm{E}<1$ indicates that the increase in domestic investment is inelastic to the performance of the fisheries sub-sector.

c. The value of the Regression Coefficient $2=0.334903$, meaning that the elasticity value of fishery business credit to the performance of the fisheries sub-sector is $E=0.334903$. The value of $\mathrm{E}<1$ indicates that the increase in fishery business credit is inelastic to the performance of the fisheries sub-sector.

d. The value of the Regression Coefficient $3=0.571480$, meaning that the elasticity value of fishery exports to the performance of the fisheries sub-sector is $E=0.571480$. The value of $\mathrm{E}<1$ indicates that the increase in fishery exports is inelastic to the performance of the fishery sub-sector.

e. The value of the Regression Coefficient $4=0.059547$, meaning that the elasticity value of the number of fishing fleets on the performance of the fishery sub-sector is $E=0.059547$. 
The value of $\mathrm{E}<1$ indicates that the increase in the number of fishing fleets is inelastic to the performance of the fisheries sub-sector.

\subsubsection{F Test}

F-statistical test is used to determine the relationship between the independent variables jointly affect the dependent variable. The F test was carried out by using the significance level and hypothesis analysis, namely the significance level or used in this study was $5 \%$. The calculation results obtained in Table 3 are a significance value of $0.00000<0.05$ which means a significant effect, indicating that the variables of domestic investment, fishery business credit, fishery exports and the number of fishing fleets simultaneously have a significant effect on the performance of the fisheries sub-sector in Indonesia. Riau Islands Province.

\subsection{3 t test}

The t-test was carried out by looking at the level of significance or where in this study the used was $5 \%$ or 0.05 . Based on the results from Table 3 , the effect of each independent variable $(\mathrm{X})$ on the dependent variable, the performance of the fisheries sub-sector in the Riau Islands province (Y).

a. Domestic Investment on the performance of the fisheries sub-sector in the province of Riau Islands, statistically shows the results of the significance of Domestic Investment less than $(0.0488<0.05)$, it can be concluded that the Domestic Investment variable has a significant and positive effect on the performance of the fisheries sub-sector in the Riau Islands Province.

b. Fishery business credit on the performance of the fisheries sub-sector in the province of Riau Islands, statistically shows the significance of fishery business credit is smaller than $(0.0024$ $<0.05)$, it can be concluded that the fishery business credit variable has a significant and positive effect on the performance of the fisheries sub-sector in the Riau Islands Province.

c. Fishery Exports on the performance of the fishery sub-sector in the Riau Islands Province statistically shows the significance of Fishery Exports is smaller than $(0.0001<0.05)$, it can be concluded that the Fishery Export variable has a significant and positive effect on the performance of the fisheries sub-sector. in the Riau Islands Province.

d. The number of fishing fleets on the performance of the fisheries sub-sector in the Riau Islands Province, statistically shows the results of the significance of the number of fishing fleets being smaller than $(0.0467<0.05)$, it can be concluded that the variable number of fishing fleets has a significant effect and positive on the performance of the fisheries subsector in the Riau Islands Province.

Based on Table 3. the results of panel data regression using the Fixed Effect Model, the variables can be sorted from the most dominant to the least influential as follows:

a. Fishery Export Variable (X3) gives the most dominant influence with a t-statistic value of 4.601201 and a significance value of 0.0001 .

b. Fishery Business Credit (X2) has the second most dominant influence with a t-statistic value of 3.307926 and a significance value of 0.0024 .

c. Fisheries Fleet. (X4) gives the third most dominant influence with a statistical t value of 2.071816 and a significance value of 0.0467 .

d. Domestic Investment Variable (X1) gives the smallest effect with a t-statistic value of 2.051290 and a significance value of 0.0488 . 


\subsubsection{Coefficient of Determination (R-Squared)}

The magnitude of the influence of domestic investment, fishery business credit, fishery exports and the number of fishing fleets simultaneously have a significant effect on the performance of the fisheries sub-sector in the Riau Islands Province as indicated by the regression results of the four independent variables on the Performance of the Fishery Subsector, namely Adjusted R Squared $=0$, 899684, which means that the magnitude of the influence of domestic investment, fishery business credit, fishery exports and the number of fishing fleets simultaneously has a significant effect on the Performance of the Fisheries SubSector of the Riau Islands Province by 89.96 percent, the remaining 10.04 percent is influenced by other factors outside the model under study.

\subsection{Discussion}

\subsubsection{The Influence of Domestic Investment, Fishery Business Credit, Fishery Exports, Number of Fishing Fleet on the Performance of the Fisheries Sub-Sector in the Riau Islands Province}

The performance of the Fisheries Sub-Sector is determined by the potential of capture fisheries in the Province. The Riau Islands are mostly located in the South China Sea and Natuna fisheries management areas with the boundaries of the Indonesian Exclusive Economic Zone (ZEEI) up to the line connecting $04^{\circ}$ South Latitude \# $106^{\circ}$ East Longitude with $03^{\circ}$ South Latitude \# $111^{\circ}$ East Longitude. To manage the potential of marine and fishery resources, the Provincial Government of the Riau Islands has given a fairly strong position in generating the economic power of marine and fisheries for the advancement of the people of the Riau Archipelago. The strong commitment of the Riau Islands Provincial Government is evidenced in the Riau Islands Province Medium Term Development Plan (RPJMD) document 2016-2021 with a vision of "The realization of the Riau Islands as the Mother of the Malay Land of Prosperity, Noble Morals, Environmentally Friendly and Superior in the Maritime Sector". Which is embodied in the 9 main missions of regional development. Performance indicators are a reference that can be used as a basis for performance appraisal. Performance indicators must be measurable so that quantitative evaluation can be carried out and can be used as a measure of the success of a program plan. The following are indicators of the performance of the Fisheries sector of the Riau Islands Province according to the program plan:

a. Capture Fisheries Development and Management Program, the performance indicators are:

1. Increasing the number of capture fisheries production (one : Ton)

2. Fisherman's Exchange Rate (NTN), (unit: Index number)

b. Aquaculture Development and Management Program. the performance indicators are:

1. Total production of aquaculture (unit: ton/year)

2. Fish Cultivator Exchange Rate (NTPi) (unit: Index number)

c. Fishery Products Competitiveness Strengthening Program, the performance indicators are:

1. Number of processed fishery products (Tons)

2. Per capita fish consumption rate ( $\mathrm{kg} /$ year) (Kg/Kapita/year)

d. Marine and Fishery Resources Management Development Program, the performance indicators are:

1. Increasing the status of marine conservation area Level III (level) 
2. Provision of management planning documents for the utilization of marine and fisheries resources (documents) To improve the performance of the fisheries sub-sector, the provincial government through the Department of Marine Affairs and Fisheries (DKP) of the Riau Islands Province, requires an appropriate strategy and policy.

The following are some of the strategies and policies set by the Department of Maritime Affairs and Fisheries of the Riau Islands Province in the Strategic Plan of the Department of Maritime Affairs and Fisheries of the Riau Islands Province.

In 2020, the performance of the fisheries sub-sector in the Riau Islands was also affected by the COVID-19 pandemic. The COVID-19 pandemic hit the fisheries business sector and marine fish cultivation in the area. The results of fish cultivation, such as grouper are usually sold to Malaysia, Singapore, and Hong Kong. However, since Covid-19 has ceased to exist, it has only been supplied to the local market, where the absorption capacity is also not optimal. The price of grouper before the pandemic was around Rp. 120 thousand per kilogram $(\mathrm{kg})$, after this covid-19 it became only Rp. 70 thousand even Rp. 50 thousand per kg. Meanwhile, snapper, star pomfret is still priced at Rp. 70 thousand per $\mathrm{kg}$. The average production value of fishery businesses in the area is now only Rp. 60 thousand per kg.

Processed fishery production before COVID-19 could reach more than one million tons in 2019, but so far it's only 685 thousand tons The majority of regions reported a significant decline in fish prices, especially certain types of fish that became export commodities. The sale of the catch is a big obstacle at this time, because many fish collectors do not serve or at least limit the purchase of fish from fishermen/cultivators. This condition causes many fishermen and cultivators to find it difficult to sell their catch, moreover, Indonesia's fishery export destination countries are also closing in on themselves, limiting their international trade transactions with other countries. This condition occurs due to the decline in people's purchasing power so that the market or Fish Auction Place becomes quiet, one of which is due to the implementation of the policy to prevent the spread of Covid-19 which has been socialized by the regional government.

\subsubsection{The Influence of Domestic Investment on the Performance of the Fisheries Sub- Sector in the Riau Islands Province}

The potential of the fisheries sector that can attract investment in the Riau Archipelago, which is more than $95 \%$ of the Riau Islands Province (Kepri) is marine waters, indicating that the potential of marine fisheries resources is very large. Broadly speaking, the types of fish resources found in the Riau Islands marine waters are: pelagic fish resource group (tuna, mackerel, mackerel, kite, anchovies and so on), demersal fish resource group [red snapper, kurisi, beloso, pomfret, etc.), reef fish resource group (grouper, baronang, napoleon, etc.), mollusk resource group (squid, cuttlefish, etc.), and crustacean resource group [crabs, crabs], and shrimp resource group.

In the capture fisheries sector, the potential of marine fish resources in the South China Sea (WPP 711) is estimated at 1,057,050 tons/year and it is estimated that the marine waters of the Riau Archipelago have potential fish resources of 860,650.11 tons/year including large pelagic fish in the amount of 53,802.34 tons/year, small pelagic fish 506,025.30 tons/year, demersal fish 272,594.16 tons/year, reef fish 17,562.29 tons/year, others (squid, shrimp, lobster) 10,666.02 tons/year. Meanwhile, with the approach of the MV research vessel survey results. SEAFDEC in 2006 estimated that the total potential of fish resources in the Riau Islands marine waters was $689,345.17$ tons/year consisting of large pelagic fish of 16,48329 tons/year, small pelagic fish of 14630934 tons/year, demersal fish of 491,653.06 tons/year, Crustaceans (Shrimp, Crab, Crab, 
Lobster, Mantis) amounted to 4402.70 tons/year, Molluscs (Squid, Cuttlefish, Octopus) amounted to $30,496.77$ tons/year. new utilization reaches $4-6 \%$ of the total potential of Natuna Regency of 504,212.85 tons/year [58.59\% of the total potential of Riau Islands Province), followed by Bintan Regency, Anambas Islands Regency, and Lingga Regency.

For investment potential in Marine Cultivation, Riau Islands Province which has a sea area of 24,121,530.0 ha (95.79\%] and a land area of 1,059,511.0 ha (4.21\%) has a very high potential for developing aquaculture. It is estimated that there are approximately 455,7799 ha of marine area that have the potential for mariculture development, consisting of 54,672.1 ha for coastal marine culture and 401,1079 ha for offshore marine culture. which is spread in almost every district/city. The high potential for mariculture development is Lingga Regency, which reaches 19,054 ha for coastal marine culture and around 226,538 ha for offshore marine culture. While according to Bappeda Kepri (2019) the investment potential in brackish and freshwater aquaculture, with a land area of 1,059,511.0 ha, Riau Islands Province has the potential for developing brackish and freshwater aquaculture which is estimated at 2,063 ha and 819 ha, respectively, and spreads in almost all districts/cities.

In relation to the natural potential and market potential for the development of the fishery sector, investment opportunities in the fishery sector that can be developed include: Pelagic fish species have a production potential of 559,928 tons/year but only 84,060 tons/year $(15.02 \%)$ are available. recently used by the community. The rest that is equal to 475,574 tons / year is a great opportunity worth Rp. 3.9 trillion/year. This great opportunity requires the provision of $60 \mathrm{GT}$ purse seine vessels as many as 416 units from industrial fisheries and a 5 GT drift gillnet fleet of 2,854 units from community fisheries. Demersal fish production is only $27.67 \%$ or 75,435 tons/year from the overall production potential is 272,594 tons/year. Thus, there are still 197,159 tons/year that can be produced annually or worth Rp. 1.38 trillion/year. This opportunity requires the provision of fishing gear in the form of basic longlines of $5 \mathrm{GT}$ and basic longlines of 60 GT totaling 1,183 units of basic longlines of 5 GT and 172 units of basic longlines of 60 GT. In addition to capture fish, there is also aquaculture potential with superior potential as follows:

a. Seawater cultivation: seaweed, fish and marine biota with high economic value as well as aquaculture products

b. Brackish water cultivation: shrimp (vannamei and tiger) and fish (milkfish, white snapper and mud grouper) cultivation. Gracilaria seaweed cultivation business.

c. Freshwater cultivation: catfish farming (Ambo catfish, sangkuriang catfish), tilapia, gourami, mujair and other freshwater fish the available market potential includes many types of consumption fish from marine aquaculture which have a high selling value. Among them, grouper fish, star pomfret and white snapper which are export commodities and are in great demand by foreign markets (Vietnam, Thailand, Iepang dan Korea). Investments that can be developed:

1. Karamba cultivation (floating nets and sticks),

2. Ponds, ponds, tubs.

3. Integrated fishery products processing business with fishing in public waters

4. Seaweed processing

5. Marketing business, distribution of fishery products

6. Chitin chitosan processing

Capture fisheries potential in Natuna Regency reaches 422,080 tons/year (Directorate General of Marine Spatial Management L, 2015, 2015, 2015). Currently, which has been utilized in 2015, capture fisheries production is recorded at only 48,699 tons or 11.54 percent of the total potential, so there are still opportunities to carry out capture fisheries business. As 
for investment opportunities in aquaculture, it can be seen from the potential area suitable for the development of marine aquaculture based on the suitability criteria is $\pm 12,997$ ha which includes coastal waters to a maximum depth of $20 \mathrm{~m}$ (according to Directorate General of Marine Spatial Management, 2015, 2015, 2015). Of the total area of land, only a small part of about 268.25 hectares $(2.06 \%)$ has been used to develop aquaculture. This shows the large opportunity for aquaculture in the Natuna Regency area. With the area of land that can still be used for aquaculture, it is estimated that there are 454,175.97 tons/year of aquaculture that can be obtained from marine aquaculture, brackish cultivation and freshwater (Directorate General of Marine Spatial Management, 2019). The results of this study are supported by previous research conducted by Kruchinina \& Ryzhkova (2020); Arida (2019); Rizal, et al (2020); Matdoan et al. (2020); Malau \& Hotman (2018); and Logunova et al. (2021) [5]; [6]; [7]; [8]; [9]; [10].

\subsubsection{The Influence of Fishery Business Loans on the Performance of the Fisheries Sub- Sector in the Riau Islands Province}

The government's program through fiscal policy in increasing access to MSME financing to financial institutions with a guarantee pattern is through the People's Business Credit (KUR). KUR is intended to improve and access financing for productive businesses, increase the competitiveness capacity of micro, small and medium enterprises as well as to encourage economic growth and employment. KUR is a bank loan that is subsidized with interest by the government, so it must be returned. The economic sector that is financed is the production sector, including the fishery sector.

Based on data from the Regional Office of the Directorate General of Treasury $(\mathrm{DJPb})$ of Riau Islands Province through the Program Credit Information System (SIKP) that the distribution of KUR 2018 until February 2018 has been distributed to 112,932 KUR debtors throughout Indonesia or has reached the realization of distribution of Rp. $2.22 \%$ of the total planned KUR ceiling in 2018 to be disbursed, which is Rp120 trillion.

In addition to financing from KUR, to improve the performance of the fisheries sub-sector through fishery business loans, the Ministry of Maritime Affairs and Fisheries (KKP) is rolling out facilities and business capital assistance to support the marine and fisheries sector in the Riau Islands Province. At least about 2.5 billion rupiah in total aid value was given to fish cultivators, fishermen, fish processors and salt farmers from Batam City and Tanjung Pinang City who attended the event. The assistance provided was in the form of fish farming production inputs (fish seeds), biofloc system fish farming packages, assistance for vessels $<5$ GT, assistance for fishing equipment, fisherman insurance, financing facilities through BLUMKP soft loans, cold chain facilities and infrastructure (ice flake machine, chest freezer), and scholarships for the main actors' children. The KKP has provided support for strategic activities that directly touch the main actors in fisheries, and this has had a positive impact on improving the economic structure of the community, particularly related to increasing income, purchasing power, and strengthening business capacity.

In general, banking institutions that serve the capital needs of fishermen in Batam are BRI, Mandiri and BNI 46. In order to provide credit, these banks conduct an analysis of the character of prospective customers, management capabilities, financial capabilities including capital and operating profit, technical aspects, business conditions and prospects, as well as collateral. The interest rate for the Inka Mina vessel gillnet business credit scheme with gillnet provided by the bank is assumed to follow the prevailing general interest rate of $14 \%$ per annum with a credit term of one to three years. 
As in the general banking system, several procedures such as a letter of credit application from the debtor, data collection (financial data, guarantees), proposal making, and submission to the credit committee must be fulfilled by prospective customers. In fulfilling these banking requirements, fishermen often face several problems including collateral problems and the preparation of activity proposals. After the administrative procedures are completed, the bank officer will collect data in the field to verify the information. After the administration and procedures are fulfilled, usually the funds will be disbursed in no more than one week. Especially for business actors in the capture fisheries sector, banks in Batam City have realized the Food and Energy Security Credit (KKPE) program with collateral obligations of $120 \%$ of the loan value. The types of loans offered are investment loans (maximum 5 years) and working capital loans (maximum 3 years). The requirement to obtain this financing is that the customer is a fisherman in Batam City as evidenced by a KTP of fishermen and submits a Definitive Plan for Group Needs (RDKK) or a Definitive Plan for Individual Needs (RDKP) which is known by the local KUD and ratified by the Batam City DKP2K.

Three state-owned banks, namely Bank Mandiri, BRI and BNI, support the distribution of People's Business Credit (KUR) in the Marine and Fisheries sector. From January to April 2020 the realization of KUR in the marine and fisheries sector (KP) only reached 44,431 people, while the number of business actors based on data from the Maritime Affairs and Fisheries Business Actor Card (KUSUKA) of the Ministry of Maritime Affairs and Fisheries (KKP), recorded 1,075,488 people or units. validated effort. Financial institutions such as banks are expected to be able to attract potential debtors in the marine and fisheries sector. Moreover, the realization of KUR in the KP sector has only absorbed Rp. 1.39 trillion with the largest percentage in the field of aquaculture business, followed by fishing, trading, services, processing and salt businesses.

The KUSUKA card is very helpful for banking institutions to find out the profile of marine and fishery business actors. Apart from being a single identity, both individuals and corporations, the KUSUKA card can also be a data base for protection and empowerment programs, including the provision of working capital, either through KUR or non-KUR. The KUSUKA card has become very important, because banks have become more confident in distributing KUR. Not only that, the profile of the business actor makes it easier for BRI to arrange the right financing according to the profile of the actor. So that the unit costs needed by business actors can be given according to their needs, along with the structure, terms and patterns of financing that can be adjusted to the pattern of the fishery business, whether seasonal or monthly.

The results of this study are supported by previous research conducted by Chauhan, Khati and Priyanka Arya (2018), Nika Pranataa (2018), Marielle van Riel, Simon R. Bush, Paul A.M. Van Zwieten, and Arthur P.j. Mol (2013), Pranata (2019); Fathoni et al. (2019); Van Riel et al. (2015); Oparinde et al. (2017); Farida et al. (2019); Laili \& Tanjung (2019) and Nazir et al. (2018). [11];[12];[13];[14];[15];[16];[17];[11].

\subsubsection{Influence of Fishery Exports on the Performance of the Fishery Sub-Sector in the Riau Islands Province}

In 2015, the total export value of the Riau Islands Province reached US\$ 11,948.98 million. This value is the lowest in the last 4 (four) years. Riau Islands Province has 22 export loading ports spread across each district/city. If viewed from the districts/municipalities loading and exporting goods, it can be seen that the largest exports of Riau Islands Province in 2015 came from Batam City, which amounted to US\$ 9,166.84 million or 76.72 percent. 
The country that became the main export destination for the Riau Islands Province in 2015 was Singapore, which was US\$ 6,394,410,282 or 53.51 percent. The next countries that become the export market share of the Riau Islands Province are Australia, Malaysia, the United States, India, China, Japan, France, the Netherlands, and other countries in Asia and Europe. As an area that has great fishery potential, Riau Islands fisheries should be able to become a mainstay of export commodities now and in the future. However, the highest export of fish and shrimp in the Riau Islands Province for the last 5 years occurred in 2015 and was only 0.58 percent or US\$ 68.84 million.

The most exported fishery commodity in Riau Islands Province in 2015 was fish, especially salmon which reached a value of US\$ 45.87 million or 66.63 percent of the total export value of fish and shrimp. In addition, other marine fish commodities, live grouper, and live crab are also the dominant export commodities in the Riau Islands Province.

Data from the Central Statistics Agency (BPS) of the Riau Islands Province recorded that until August 2017 the export value of fish and shrimp had just touched US\$14 million. Whereas in 2016, fish and shrimp exports reached 22 million US dollars. Meanwhile, fresh marine fish occupies the top position which is exported as much as 76.37 percent in 2016 then in 2017 to August at 61.62 percent, then followed by Grouper as much as 12.47 percent in 2016 and 17.49 percent in 2017, Salmon increased from 0. 36 percent in 2016 to 7.05 percent in 2017 to August, Live Crab by 2.57 percent in 2016 and increased to 3.76 in 2017 to August, Shark fin as much as 2.25 percent in 2016 and to date in 2017 increased to 2.56 percent. For the purpose of exporting this fish, Singapore is the main export destination. Then occupy the second position in Hong Kong, then Malaysia and Japan. The main export commodities of fishery products in the Riau Islands Province vary greatly each year and depend on various international market demands. Riau Islands Province must improve the implementation of a quality assurance system that is in line (harmonious) with the quality assurance system of export destination countries, especially for fishery commodities. This is done to minimize cases of export refusal by destination countries, especially European Union countries that have a Rapid Alert System for Food and Feed (RASFF) to maintain the quality and safety of export commodities entering the country.

The quality aspect is a very decisive factor in the trade of fishery products in the international market. Consumers of fishery products, which are developed countries, have high standards and sensitivity to the quality of fishery products traded in the international market. As an area that has a fairly large export potential of fishery products, the regional government of the Riau Islands Province is expected to conduct a study on the causes of the low export value of fishery products. In addition, the government can build systems and supporting units needed to boost quality fishery production so that exports of fishery products can increase every year.

To spur export trade growth in the midst of the global economic slowdown due to the current Covid-19 pandemic, the opportunity for improvement from the fishery sector can still be relied on. The Ministry of Maritime Affairs and Fisheries (KKP) strives to provide the logistics facilities needed to meet the raw material needs of the Fish Processing Unit (UPI) with the aim of exporting as one of the efforts to restore the national economy. As has been done by the KKP through the Tanjungpinang Fish Quarantine, Quality Control and Fishery Product Safety Center (Balai KIPM), which provides Fishery Product Export Certification services for export to Singapore from Bintan Regency, Riau Islands Province (Kepri). In the midst of the Covid-19 pandemic, the fishery business, especially in Bintan Regency, is still running well and the quality of fishery products has been guaranteed.

The types of commodities exported consist of 5 types of products, namely White snapper/anggoli fillet, White snapper/anggoli half head, White snapper/anggoli tail, Spanish 
mackerel/rod fillet and grouper minch meat worth 73,750 SGD or if the exchange rate is converted to Rupiah, it becomes Rp. Rp. 811,250,000 (eight hundred and eleven million two hundred and fifty thousand rupiah) with a total volume of $11,000 \mathrm{Kg}$. In general, so far, products sent to Singapore in fresh form are sent by the Fish Processing Unit in the Bintan Region, so they are vulnerable to a decline in product quality due to the shipping and handling processes that cannot maintain the product cold chain system, with a breakthrough in sending directly in the form of Frozen has the advantages of a more optimal amount of load, the shelf life of the product is also longer, the quality is better maintained.

The results of this study are supported by previous research conducted by Sitompul, Tiurmaida \& Sahara, Sahara \& Anggraeni, Lukytawati (2018), VuThuy Duong, Le Thu Ha, and Francesca Masciarelli (2020), Burhaz, M. \& Matviienko, T. \& Soborova, O. \& Bezyk, K. \& Kudelina, O. \& Lichna, A. (2020), Babar et al. (2018); Vu Thuy et al. (2020); Burhaz et al. (2020); Shamsuzzaman et al. (2020); and Demirci et al. (2020). [18]; [19]; [20]; [21]; [20]; [22]; [23].

\subsubsection{Influence of Fishing Fleet on the Performance of the Fisheries Sub-Sector in the Riau Islands Province}

Prospect of fishery business in this province is very good because it is close to the destination of export fish markets, namely to border countries such as Singapore, Malaysia and Thailand. The export fish commodities consist of various types of reef fish, types of shrimp, crabs and small crabs as well as large pelagic fish species, namely mackerel species, which include the results of the Fleet fishing for hand-line catches. The types of fish produced by the hand-line fishing fleet include important economically important fish species that are highly saleable in the export market, such as snapper, grouper and mackerel. In addition, the price of the type of fish caught by hand line is higher than the type of fish caught by other fishing gear because the types of hand line fish are still in good physical condition and fresh so that the quality is also better.

For example, in the city of Tanjung Pinang, the number of hand-line fishing trips is 16 trips/year (an average of 2 trips for every 1.5 months), while the number of days of operation varies between 10-15 days/trip, except during the tuna fishing season. The number of operating days is faster, which is under 10 days/trip. The fishing boats for Tanjung Pinang fishermen are generally made of wood. The tools available consist of a fish finder and a Global Positioning System (GPS). Hand-drawn fishing boats consist of the main line (main line), kilikili (swivel), hook (hook) and some use a branch line (branch line), and sinkers (sinkers). The fishing rods used by fishermen in Tanjung Pinang consist of four types, namely handline fishing rods for bait fish, line fishing rods for reef fish, line fishing rods for mackerel and line fishing rods for cob.

a. Fleet with bait fish Fishing with handline fishing gear generally uses bait fish, both artificial bait fish and natural bait fish. Artificial bait fish are provided and prepared before going to sea. While natural bait fish are prepared before going to sea by buying bait fish caught by fishermen (bagan) or by fishing first. At the time of departure, the hand line fisherman brought about $80 \mathrm{~kg}$ of bait fish purchased from local fishermen for 10 days. Types of bait fish used include tembang (Clupeidae), mackerel (Scombridae) and selar (Carangidae). The fish is brought fresh, stored in a box and given ice and salt. To increase the supply of bait fish, fishermen usually fish for bait fish using vertical longline fishing rods. Vertical longline fishing using line number 18 as many as 20 hooks for one long line fishing line. Fishing for 
bait fish is carried out in the waters around FADs at a depth of 45 meters in the morning before operating the hand line and in the afternoon after operating the hand line.

b. Fleet with reef fishing line Reef fishing rods use hook number 6 . The type of hook is a hooked hook. In a set of hand lines there are 5 branch lines with a length of each branch line $70 \mathrm{~cm}$ and a distance between branch lines 1 meter. The main rope is made of nylon monofilament number 150 while the branch rope uses nylon monofilament number 90 . In operation, the fishing line is equipped with fresh bait fish. The types of bait fish used were tembang, mackerel and selar fish which were cut into 3 parts. At the bottom of the main rope is given a weight made of iron weighing $1 \mathrm{~kg}$.

c. Fleet with mackerel fishing line. The fishing rod for mackerel (fishing mackerel) uses fishing rods number 4 and number 7 which are strung together. The two types of hooks are hooked hooks. The main line uses a number 40 monofilament string. During operation, the fishing line is equipped with fresh bait fish of 15-20 cmFL size. The types of bait fish consist of tembang, mackerel and selar fish. At the bottom of the main rope is given a weight made of iron weighing $0.5 \mathrm{~kg}$.

d. Fleet with tuna fishing line. The fishing line for tuna (cob line) uses hook number 9. The type of fishing line is a hook type. At the time of operation, this fishing line is equipped with feathers made of silk thread which function to cover the fishing line and attract the target fish to eat it. In a series of main ropes there are 40 branch ropes as a place to install the fishing rod unit. The main rope at the top uses nylon monofilament number 100, then at the bottom it uses nylon rope number 90 , number 70 and the bottom is number 40 . The main ropes are connected to each other by swivel. At the bottom of the main line, a fishing rod is attached and is not weighted (unlike the reef and mackerel fishing rods).

The results of this study are supported by previous research conducted by Yeyen Mardyani, and Atik Yulianti (2020), Lukman Adam (2018), Sergey S. Moiseenko \& Leonid E. Meyler (2018); Teniwut (2016); Adam (2018); Malau \& Hotman (2018); Picaulima, et al. (2020); and Tawari et al (2016) [24];[25];[26];[25];[8];[27];[28].

\section{Conclusion}

Investasi Domestic investment that continues to increase, greater distribution of fishery business credit with low interest, the level of fishery exports that has increased every year and is supported by a large number of fishing fleets equipped with modern equipment have proven to have a very significant influence on the success of the sub-district. fisheries sector in improving its performance in the Riau Islands Province. A conducive domestic investment climate in the fisheries sector has made a major contribution in encouraging the improvement of the performance of the fisheries sub-sector in the Riau Islands Province. The implementation of Bank Indonesia's People's Business Credit program in the fisheries sector carried out by the banking sector by extending larger loans with low interest has proven to be able to boost the performance of the fisheries sub-sector in the Riau Islands Province. The main export commodities of fishery products in the Riau Archipelago Province vary greatly every year and depend on the variety of international market demand which is quite high and the quality aspect that becomes a priority is a very decisive factor in the trade of fishery products on the international market so that the export value of fishery commodities can improve the performance of the sub-sector. fisheries in the Riau Islands Province. The large number of fishing fleets scattered throughout the regencies/cities and equipped with modern fishing 
equipment make the fish catches of the fishermen much more productive so as to improve the performance of the fisheries sub-sector in the Riau Islands Province.

\section{References}

[1] Arsyad (2015). Ekonomi Pembangunan dan Pembangunan Ekonomi. In Ekonomi Pembangunan Berkelanjutan (Vol. 05, Issue 01).

[2] Hempel, G, and Pauly, D. (2002). Fisheries and Fisheries Science in Their Search for Sustainability. pp 109 - 135. In: J.G. Field, G. Hempel and C.P. Summerhawes (eds.) Oceans 2020: Science, trends and challenges Sustainability. Island Press. Washington.

[3] Lackey R.T. Fisheries: Histroy, Science and Management. pp.121-129. In: Water Encyclopedia: Surface and Agricultural Water, Jay H. Lehr and Jack Keeley, editors, John Wiley and Sons, Inc. Publishers, New York, pp.781 (2005).

[4] Mubyarto. Pengantar Ekonomi Pertanian. Pustaka LP3ES, Jakarta (1994)

[5] Kruchinina, V. M., \& Ryzhkova, S. M. Analysis of the potential investment attractiveness of the Russian fisheries sector. Proceedings of the Voronezh State University of Engineering Technologies, 82(1) (2020). https://doi.org/10.20914/23101202-2020-1-322-332

[6] Rizal, A., Nurruhwati, I., \& Apriliani, I. M. (2020). Macroeconomic Factors Influencing the Fisheries Sector Investment in Bandung City of West Java, Indonesia. The International Journal of Business Review (The Jobs Review), 3(1), 110.https://doi.org/https://doi.org/10.17509/tjr.v3i1.25040rizal

[7] Arida, A. Pengaruh Investasi Sektor Perikanan Terhadap Perekonomian Indonesia. Jurnal Penelitian Agrisamudra, Vol. 6, (2) (2019). https://doi.org/10.33059/jpas.v6i2.882

[8] Matdoan, A., Wahyuningsih, T., \& Laitupa, A. A. Pengaruh Investasi, Subsektor Perikanan, Dan Pertumbuhan Ekonomi Terhadap Kesempatan Kerja Di Maluku. Media Trend, Vol. 15 (1) (2020). https://doi.org/10.21107/mediatrend.v15i1.6638

[9] Malau, A. G., \& Hotman, J. (2018). Impact of Government Policy on Fisheries Production, Number of Fleet Fisheries, Investment, Fisheries Household in Batam City. International Journal of Economics and Financial Issues, 8(6).

[10] Logunova, N., Glechikova, T., \& Kotenev, A. Investment Attractiveness of the Area for Marine Farming and Marine Aquaculture Target Species. Transportation Research Procedia, 54 (2021). https://doi.org/10.1016/j.trpro.2021.02.051

[11] Nazir, I., Chauhan, RS., Khati, A., \& Arya P. The Role of credit for the upliftment of the fisheries sector. International Journal of Fisheries and Aquatic Studies; 6(2): 01-04 (2018)

[12] Pranata, N. Financial inclusion in Indonesia's fishery sector: Factors determining credit participation. Institutions and Economies, Vol. 11 (4) (2019). https://ijie.um.edu.my/index.php/ijie/article/view/19662/10408

[13] Fathoni, S., Rachman, M. A., \& Arasy, A. K. (2019). Analysis determinant supply \& demand fisheries. IOP Conference Series: Earth and Environmental Science, 241(1). https://doi.org/10.1088/1755-1315/241/1/012030

[14] Van Riel, M. C., Bush, S. R., van Zwieten, P. A. M., \& Mol, A. P. J. Understanding fisheries credit systems: Potentials and pitfalls of managing catch efficiency. Fish and Fisheries, 16(3) (2015). https://doi.org/10.1111/faf.12066 
[15] Oparinde, L. O., Amos, T. T., \& Adeseluka, M. Influence of Agricultural Credit Guarantee Scheme Fund (ACGSF) On Fishery Development in Nigeria. Economic Engineering in Agriculture and Rural Development, 17(1) (2017)

[16] Farida, F., Wahyuni, N., \& Zulfida, I. Keterkaitan Efisiensi Kredit Usaha Rakyat (KUR) dengan Topografi Wilayah di Kabupaten Pati, Provinsi Jawa Tengah. Journal of Regional and Rural Development Planning, 3(2). (2019) Derived from https://doi.org/10.29244/jp2wd.2019.3.2.117-130

[17] Laili, N., \& Tanjung, H. Analysis of Factors Affecting Islamic Bank Financing for the Fisheries Sector in Indonesia. Abdimas Talenta, Jurnal Pengabdian Kepada Masyarakat, Vol. 4(2) (2019). https://doi.org/10.32734/abdimastalenta.v4i2.4176

[18] Sitompul, T. K., Sahara, S., \& Anggraeni, L. (2018). The Effects of Trade Facilitation on Indonesian Fisheries Export. Jurnal Manajemen Dan Agribisnis. https://doi.org/10.17358/jma.15.3.230

[19] Vu Thuy, D., Le Thu, H., \& Francesca, M. The economic impact of CPTPP on Vietnam's fisheries exports to CPTPP region. Journal of International Economics and Management (2020) https://doi.org/10.38203/jiem.020.2.0007

[20] Burhaz, M. I., Matviienko, T. I., Soborova, O. M., Bezyk, K. I., Kudelina, O. Y., \& Lichna, A. I. (2020). Modern state of fish and fishery products export in Ukraine. Ukrainian Journal of Veterinary and Agricultural Sciences, Vol. 3(1) (2020). https://doi.org/10.32718/ujvas3-1.04

[21] Babar, S., Shah, H., Mu, Y., Abbas, G., Pavase, T. R., Mohsin, M., Malik, A., Ali, M., Noman, M., \& Soomro, M. A. An economic analysis of the fisheries sector of Pakistan (1950-2017): Challenges, opportunities and development strategies. International Journal of Fisheries and Aqatic Studies, 6(2) (2018)

[22] Shamsuzzaman, M. M., Hoque Mozumder, M. M., Mitu, S. J., Ahamad, A. F., \& Bhyuian, M. S. (2020). The economic contribution of fish and fish trade in Bangladesh. In Aquaculture and Fisheries (Vol. 5, Issue 4). https://doi.org/10.1016/j.aaf.2020.01.001

[23] Demirci, A , Şimşek, E , Can, M , Akar, Ö , Demirci, S . (2020). Has the pandemic (COVID-19) affected the fishery sector in regional scale? A case study on the fishery sector in Hatay province from Turkey. Marine and Life Sciences, Vol. 2 (1), pp. 13-17 (2020)

[24] Mardyani, Y., \& Yulianti, A. Analisis Pengaruh Sub Sektor Perikanan Terhadap Pertumbuhan Ekonomi Di Provinsi Kepulauan Bangka Belitung. Equity: Jurnal Ekonomi, Vol. 8(2) (2020).. https://doi.org/10.33019/equity.v8i2.47

[25] Adam, Lukman (2018). Obstacle and Strategy to Improve Indonesia's Exports of Fisheries Product. (Pusat Penelitian Badan Keahlian DPR RI, Nusantara II). http://jurnal.dpr.go.id/index.php/kajian/article/view/1871/87

[26] Teniwut, W. A. (2016). For sustainable revenue of fisheries sector in small islands: Evidence of Maluku, Indonesia. AACL Bioflux, 9(3). https://doi.org/10.5281/zenodo.245507

[27] Picaulima, S., Wiyono, E. S., Baskoro, M. S., \& Riyanto, M. (2020). Klasterisasi Armada Perikanan Skala Kecil Di Pulau Kei Kecil Bagian Timur, Kepulauan Kei. Jurnal Ilmu Dan Teknologi Kelautan Tropis, 12(3). https://doi.org/10.29244/jitkt.v12i3.31974

[28] Tawari, R. H. S., Simbolon, D., Purbayanto, A., \& Taurusman, A. A. Analisis Optimasi Armada Penangkapan Madidihang Skala Kecil di Kabupaten Seram Bagian Barat (Fishing Fleet Optimization Analysis of Small-Scale Yellowfin Tuna in West Seram Regency). Marine Fisheries: Journal of Marine Fisheries Technology and Management, Vol. 5(2) (2016) https://doi.org/10.29244/jmf.5.2.129-137 
[29] Agustiani, Y., \& Syechalad, M. Analisis Faktor-faktor yang Mempengaruhi Konstribusi Sektor Perikanan Terhadap PDRB di Aceh. Jurnal Ilmiah Mahasiswa (JIM), Vol.1 No.2, pp. 494-503 (2016)

[30] Agustini, Y., \& Panca Kurniasih, E. (2017). Pengaruh Investasi PMDN, PMA, dan Penyerapan Tenaga Kerja Terhadap Pertumbuhan Ekonomi dan Jumlah Penduduk Miskin Kabupaten/Kota di Provinsi Kalimantan Barat. Jurnal Ekonomi Bisnis Dan Kewirausahaan, 6(2). https://doi.org/10.26418/jebik.v6i2.22986

[31] Aminda, R. S., \& Rinda, R. T. Laju Investasi Bentuk Pertumbuhan Ekonomi Indonesia Tahun 2008-2017. Inovator, 8(2) (2019). https://doi.org/10.32832/inovator.v8i1.2505

[32] As, A., Humairani, R., Purnama, N., \& Ayuzar, E. (2020). Marine Fisheries and Aquaculture Production of Indonesia: Recent Status of GDP Growth. Journal of Marine Science Research and Oceanography, 3(4). https://doi.org/10.33140/jmsro.03.04.04

[33] Efendi, A., Syechalad, M., Seftarita, C., \& Jamal, A. (2018). The Effect of Fisheries Sectors on Economic Growth in Aceh-Indonesia. Int. j. of Social Science and Economic Research, 4(3), 1979-1991.

[34] Gaurahman, F., \& Arka, I. N. P. Analisis Pengaruh Sektor Perikanan Terhadap Pertumbuhan Ekonomi di Kabupaten Mimika.. JURNAL KRITIS (Kebijakan, Riset, dan Inovasi), 4(1SE-Articles). (2020). Derived from http://ejournal.stiejb.ac.id/index.php/jurnal-kritis/article/view/105

[35] Hung, Fu-Sheng dan Cothern, Richard. (2002). Credit market development and economic growth. Journal of Economics and Business, Vol. 54: 219-237.

[36] Hutajulu, H., Imran, Z., Budiharsono, S., \& Kusumastanto, T. (2019). Economic structure analysis in the development of skipjack tuna (Katsuwonus pelamis) fisheries industry in Jayapura City, Papua, Indonesia. AACL Bioflux, 12(5), 1726-1737.

[37] Kanchana, S., \& Rajamohan, S. (2021). Impact of Covid-19 on Fisheries Sector. Shanlax International of Journal Management, https://doi.org/10.34293/management.v9i1.3853

[38] Kusdiantoro, Achmad Fahrudin A, Wisudo S., \& Juanda B. (2019). The economic impact of capture fisheries development in Indonesia. Journal article: $A A C L$ Bioflux Vol.12 No.5 pp.1698-1709. https://doi.org/10.15578/marina.v5i2.8053

[39] Kuznets, Simon. (1955). Economic Growth and Income Inequality. American Economic Review 45 (March): 1-28

[40] Lucky Rachmawati, Djoko Mursinto, N. I. (2017). Fishery's Potential in Indonesia. International Journal of Humanities and Social Science Invention, 6(2).

[41] Manik, T. (2019). Development of Maritime Economy and Coastal Economy to Improve Competitiveness and Coastal Economic Growth in Riau Island Province. ECSOFiM: Journal of Economic and Social of Fisheries and Marine. 06(02):158-172. http://dx.doi.org/10.21776/ub.ecsofim.

[42] Matondang, H., Zulkarnaini, \& Yulinda, E. (2017). The Contribution Of Fisheries Subsector Toward Gross Regional Domestic Product Of Tanjungbalai Asahan City North Sumatra Province.

[43] Maulida, A., \& Nasir, M. (2018). Analisis Peranan Sub Sektor Perikanan Terhadap Pertumbuhan Ekonomi di Provinsi Aceh. Jurnal Ilmiah Mahasiswa (JIM) Ekonomi Pembangunan Fakultas Ekonomi dan Bisnis Unsyiah Vol.3 No.4 : 687-695

[44] Minahal, Q., Munir, S., Komal, W., Fatima, S., Liaqat, R., \& Shehzadi, I. (2020). Global impact of COVID-19 on aquaculture and fisheries: A review. International Journal of Fisheries and Aquatic Studies, 8(6).

[45] Mulyadi (2007). Ekonomi Kelautan. Jakarta: PT. Raja Grafindo Persada 
[46] Musa, D., Yapanto, L., Tanipu, F., \& Suherman, S. (2020). The Impact of Covid-19 on Supply Chain Fisheries and Challenges by Fisherman in Indonesia. Journal of University of Shanghai for Science and Technology, 22(10), 1360-1365.

[47] Purkait, S., Karmakar, S., Chowdhury, S., Mali, P., \& Sau, S.K. (2020). Impacts of Novel Coronavirus (COVID-19) Pandemic on Fisheries Sector in India: A Minireview, Ind. J. Pure App. Biosci. 8(3), 487-492. doi: http://dx.doi.org/10.18782/2582-2845.817

[48] Putong, Iskandar (2013). Economics, Pengantar Mikro dan Makro, Edisi Kelima. Jakarta: Mitra Wacana Media.

[49] Rahmizal, M. (2017). Analysis of Indonesia Marine Fisheries with Economic Growth, Population and Effort Effectiveness. European Journal of Engineering and Formal Sciences, 1(1). https://doi.org/10.26417/ejef.v1i1.p17-22

[50] Rustan. (2019). Pusaran Pembangunan Ekonomi. Makassar: CV Sah Media.

[51] Schumpeter, J. A. (1934). The Theory of Economic Development: An Inquiry into Profits, Capital, Credit, Interest and the Business Cycle. Cambridge, MA: Harvard University Press. Original Work Published.

[52] Siregar, H. P., Rizal, A., Hamdani, H., \& Gumilar, I. (2020). The Contribution of Fisheries Sector in Regional Development of Batam City of Riau Islands Province, Indonesia. Asian Journal of Fisheries and Aquatic Research. https://doi.org/10.9734/ajfar/2020/v7i330118

[53] Sudarmo, A.P., M.S. Baskoro, B. Wiryawan, E.S. Wiyono, \& D.R. Monintja. (2015). Analysis of production factors of small-scale fisheries using arad nets in Tegal City, Indonesia. Developing Country Studies, 5(4): 98-104. http://www.iiste.org/Journals/index.p hp/DCS/article/download/19659/201 28

[54] Syamsuri, H., Amril \& Dien Triana, D. (2018). The Strategy of Increasing Economic Growth of the Maritime Sector: South Sulawesi Analysis Context. IOP Conf. Series: Earth and Environmental Science 175(1) https://iopscience.iop.org/article/10.1088/1755-1315/175/1/012226

[55] Todaro, M. P., \& Smith, S. C. (2014). Economic Development, Twelfth edn. Pearson Addison Wesley, Boston.

[56] Widyastuti, A., \& Nugraha, J. (2021). Pengaruh Investasi, Tenaga Kerja dan Produksi Perikanan Terhadap Pertumbuhan Ekonomi Pulau Jawa. INDEPENDENT: Journal Of Economics, 1(1), 222-239

[57] Wiradana, P. A., Widhiantara, I. G., Pradisty, N. A., \& Mukti, A. T. (2021). The impact of COVID-19 on Indonesian fisheries conditions: opinion of current status and recommendations. IOP Conference Series: Earth and Environmental Science, 718(1), 12020.

[58] Yapanto M Lis, Musa Th Dahniar, Tanipu, F., \& Suherman, S. P. (2020). The Impact of Covid-19 on Supply Chain Fisheries and Challenges by Fisherman in Indonesia. Journal of University of Shanghai for Science and Technology, 22(10), 1360-1365. 